\title{
IJCIT
}

(Indonesian Journal on Computer and Information Technology) Journal Homepage: http://ejournal.bsi.ac.id/ejurnal/index.php/ijcit

\section{Perancangan Sistem Pakar Penentuan Jenis Kulit Wajah Menggunakan Metode Certainty Factor}

\author{
Rangga Pebrianto ${ }^{1}$, Siti Nurhasanah Nugraha ${ }^{2}$, Windu Gata ${ }^{3}$ \\ Ilmu Komputer, STMIK Nusa Mandiri \\ Jakarta, Indonesia \\ e-mail: 14002396@nusamandiri.ac.id ${ }^{1}$, 14002394@nusamandiri.ac.id ${ }^{2}$, windu@nusamandiri.ac.id ${ }^{3}$
}

\begin{abstract}
A B S T R A K
Wajah adalah bagian tubuh terpenting yang harus selalu dijaga dan dirawat. Sehingga banyak cara merawat wajah yang dilakukan untuk mendapatkan wajah putih, bersih, dan terbebas dari jerawat. Pengetahuan analisa kulit wajah sangat diperlukan untuk menentukan jenis kulit serta produk perawatan yang sesuai dengan jenis kulit. Sistem pakar merupakan sistem yang mengadopsi pengetahuan dari seorang pakar dan dapat berperan layaknya seorang pakar dalam menangani proses konsultasi. Tujuan dari penelitian ini yaitu merancang sebuah sistem pakar yang dapat menentukan jenis kulit wajah berbasis android dengan menerapkan metode certainty factor dalam proses penghitungan derajat tingkat keyakinan. Dengan aplikasi sistem pakar berbasis android ini konsultan dapat melakukan pemeriksaan dengan mudah, dan pendiagnosaan sekaligus solusi dapat terselesaikan secara cepat dan tepat berdasarkan data yang diinputkan.
\end{abstract}

Katakunci: Android, Certainty Factor, Perancangan Sistem Pakar

\begin{abstract}
A B STRACTS
Face is the most important body part that should always be kept and cared for. So many ways of taking care of the face are done to get the face of white, clean, and free of acne. The knowledge of facial skin analysis is necessary to determine the skin type as well as care products that suit the skin type. The expert system is a system that adopts the knowledge of an expert and can play like an expert in handling the consultation process. The purpose of this research is to design an expert system that can determine the type of Android-based facial skin by applying the certainty factor method in the process of counting degrees of confidence. With this Android-based expert System Application consultants can perform inspections with ease, and the solution can be easily resolved quickly and precisely based on the data being inputed.
\end{abstract}

Keywords: Android, Certainty Factor, Expert System Design

\section{PENDAHULUAN}

Kulit merupakan pembungkus yang elastik yang melindungi tubuh dari pengaruh lingkungan. Kulit juga merupakan alat tubuh yang terberat dan terluas ukurannya, yaitu $15 \%$ dari berat tubuh dan luasnya 1,50-1,75 m2 Ratarata tebal kulit $1-2 \mathrm{~mm}$, paling tebal $(6 \mathrm{~mm})$ ada ditelapak tangan dan kaki dan paling tipis $(0,5$ $\mathrm{mm}$ ) ada di penis (Putra \& Winaya, 2018). Kulit terbagi atas tiga lapisan pokok yaitu epidermis, dermis atau korium, dan jaringan subkutan atau subkutis (Berliana, 2015). Menjaga kulit wajah agar selalu segar dan sehat adalah investasi masa depan. Untuk itu hal yang harus kita ketahui sebelum melakukan perawatan adalah mengetahui jenis kulit wajah kita.

Kulit wajah merupakan bagian paling sensitif dibandingkan kulit bagian (Wardah, Sugiarto, \& Wibowo, 2019). Wajah mengalami 
berbagai perubahan yang disebabkan pengaruh lingkungan luar seperti pengaruh sinar matahari, iklim, polusi, penggunaan AC, trauma pada kulit, dan penggunaan produk perawatan atau tata rias yang tidak sesuai, maupun perubahan dari dalam tubuh misalnya pengaruh perubahan hormonal pada saat pubertas, menstruasi,kehamilan, pil KB, pengaruh zat gizi (nutrisi), dan lain-lain.

Jafra merupakan perusahaan yang di didirikan oleh Ja and Frank di Malibu Amerika 61 tahun lalu jafra bergerak di bidang kosmetik dan skin care masuk ke indonesia baru 5 tahun. Jafra teriri dari banyak jaringan salah satu pendirinya Ibu Linda Garminia sebagai pendiri D'Tops $B y$ Jafra dengan prinsip bekerja healthing people atau membantu orang terutama membantu para wanita agar bisa memiliki penghasilan sendiri dan menjadi lebih produktif. D'Tops $B y$ Jafra beralamat di Jl. Mujaer Kaler, No.3, Buah Batu, Bandung 40262. Konsumen yang berkonsultasi dengan konsultan jafra kebanyakan mereka yang sudah mengalami efek dari penggunaan produk yang tidak sesuai dengan jenis kulit wajah, pada akhirnya menimbulkan masalah baru. Semua itu sebagian besar disebabkan karena ketidaktahuan, mengikuti produk yang digunakan orang lain yang belum tentu jenis kulitnya sama. Selain itu disebabkan sebagian orang enggan bertanya langsung ke pakar seperti dokter spesialis kulit, maupun konsultan produk perawatan wajah dikarenakan pola fikir mereka kalau konsultasi dengan pakar itu memerlukan biaya yang cukup mahal.

Untuk itu perlunya ada penelitian dalam membangun dan mengembangkan suatu sistem pakar untuk melakukan diagnosa jenis kulit wajah dan produk jafra yang cocok dengan jenis kulitnya. Diharapkan penelitian ini dapat bermanfaat untuk memberikan pengetahuan tentang jenis kulit wajah dan penggunaan produk jafra sesuai dengan jenis kulitnya.

Dalam bidang kesehatan, telah banyak aplikasi komputer yang diciptakan untuk membantu efisiensi kerja. Salah satu aplikasi tersebut adalah sistem pakar yang merupakan salah satu cabang dari kecerdasan buatan atau Artificial Intelligent (Al). Sistem pakar mempunyai kemampuan untuk memecahkan masalah-masalah praktis saat sang pakar berhalangan (Hernawan \& Sidiq, 2018). Knowledge (pengetahuan) dalam sistem pakar bisa dari seorang ahli, atau knowledge pada umumnya yang terdapat dalam buku, majalah, dan orang yang mempunyai pengetahuan tentang suatu bidang.

Menurut (Durkin, 1994), sistem pakar adalah program komputer yang didesain untuk meniru kemampuan memecahkan masalah dari seorang pakar. Pakar adalah orang yang memiliki kemampuan atau mengerti dalam menghadapi suatu masalah lewat pengalaman, seorang pakar mengembangkan kemampuan yang membuatnya dapat memecahkan permasalahan dengan hasil yang baik dan efisien. Sistem pakar yang baik dirancang agar dapat menyelesaikan suatu permasalahan tertentu dengan meniru kerja dari ahli (Diah \& Murti, 2014).

Penelitian tentang sistem pakar sudah banyak diteliti oleh beberapa peneliti. Penelitian yang dilakukan oleh (Septiana, 2016), yang mendiagnosa tentang penyakit ISPA dengan metode certainty factor berbasis android. Hasil dari penelitian ini yaitu keluaran berupa kemungkinan penyakit ISPA yang diderita berdasarkan gejala yang dirasakan. Selain itu penelitian sistem pakar yang dilakukan oleh (Syatibi, 2019), yang menghasilkan sebuah aplikasi sistem pakar yang dapat digunakan untuk mendiagnosa kemungkinan penyakit kulit pada sapi. Penelitian oleh (Permatasari, 2019) menghasilkan sebuah sistem pakar yang dapat digunakan untuk mendiagnosa jenis kulit wajah wanita dalam memilih kosmektik.

Penelitian sistem pakar ini akan menggunakan metode Certainty Factor (CF) yang bekerja dengan cara menunjukkan ukuran kepastian terhadap suatu fakta atau aturan. Metode ini melakukan penalaran layaknya seorang pakar, dan untuk mendapatkan nilai kepercayaan (Santi \& Andari, 2019). Beberapa penelitian yang menggunakan metode CF diantaranya (Saputra, 2017) yang mendiagnosa penyakit kulit, (Septiana, 2016) diagnosa penyakit ISPA, dan diagnosa masalah kulit untuk ketepatan perawatan wajah yang dilakukan oleh (Berliana, 2015).

\section{METODE PENELITIAN}

Pada penelitian ini metode penelitian yang digunakan diantaranya metode waterfall, metode pengumpulan data, dan metode certainty factor. Metode waterfall digunakan untuk metode pengembangan perangkat lunak yang terdiri dari analisis kebutuhan, desain sistem dan implementasi. Dalam melakukan pengumpulan data, penulis melakukan 
pengamatan langsung yaitu dengan melihat beauty class Jafra. Selain itu, penulis melakukan wawancara langsung bersama pihak Jafra untuk mendapatkan informasi yang lebih jelas.

Penelitian ini menggunakan metode Certainty Factor (CF) yang menunjukan ukuran kepastian terhadap fakta dan aturan. Berikut ini adalah notasi factor kepastian.

$\mathrm{CF}(\mathrm{h}, \mathrm{e})=\mathrm{MB}(\mathrm{h}, \mathrm{e})-\mathrm{MD}(\mathrm{h}, \mathrm{e})$ dimana:

$\mathrm{CF}(\mathrm{h}, \mathrm{e})$ : factor kepastian

MB (h,e): ukuran kepercayaan terhadap hipotesis $\mathrm{h}$, jika diberikan evidance e (antara 0 dan 1).

$\mathrm{MD}(\mathrm{h}, \mathrm{e})$ : ukuran ketidakpercayaan terhadap hipotesis $h$, jika diberikan evidance e (antara 0 dan 1).

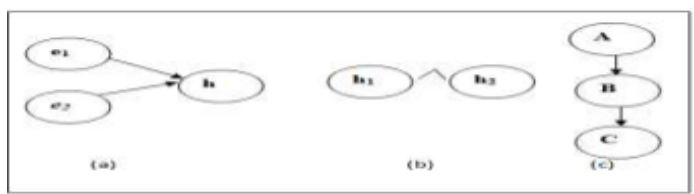

Gambar 1. Aturan Ketidakpastian

Gambar 1 menunjukkan 3 hal yang mungkin terjadi. Beberapa evidance dikombinasikan untuk menentukan $C F$ dari suatu hipotesis. Jika $e_{1}$ dan $e_{2}$ adalah observasi, maka:

$M B\left[h, e_{1} e_{2}\right]=\left\{M B\left[h, e_{1}\right]+M B\left[h, e_{2}\right] .\left(1-M B\left[h, e_{1}\right]\right)\right\}$

$M B\left[h, e_{1}^{\wedge} e_{2}\right]=\left\{M D\left[h, e_{1}\right]+M D\left[h, e_{2}\right] \cdot\left(1-M D\left[h, e_{1}\right]\right)\right\}$
CF dihitung dari kombinasi beberapa hipotesis. Jika $\mathrm{h}_{1}$ dan $\mathrm{h}_{2}$ adalah hipotesis, maka: $M B\left[h_{1} \wedge h_{2}, e\right]=\min \left(M B\left[h_{1}, e\right], M B\left[h_{2}, e\right]\right)$

$M B\left[h_{1} v h_{2}, e\right]=\max \left(M B\left[h_{1}, e\right], M B\left[h_{2}, e\right]\right)$

$M D\left[h_{1} \wedge h_{2}, e\right]=\min \left(M D\left[h_{1}, e\right], M D\left[h_{2}, e\right]\right)$

$M D\left[h_{1} v h_{2}, e\right]=\max \left(M B\left[h_{1}, e\right], M B\left[h_{2}, e\right]\right)$

\section{HASIL DAN PEMBAHASAN}

\subsection{Perhitungan Metode Certainty Factor}

Tabel 1. Kode Jenis Kulit

\begin{tabular}{|c|c|}
\hline Kode jenis & Nama jenis kulit \\
\hline A & Kulit Normal \\
\hline B & Kulit Kering \\
\hline $\mathrm{C}$ & Kulit berminyak \\
\hline $\mathrm{D}$ & Kulit Kombinasi \\
\hline $\mathrm{E}$ & Kulit Sensitif \\
\hline \multicolumn{2}{|r|}{ Tabel 2. Kode Gejala } \\
\hline \multicolumn{2}{|r|}{ Nama ciri - ciri Kulit Wajah } \\
\hline 1 & Berkomedo \\
\hline 2 & Berminyak seluruh wajah \\
\hline 3 & Berminyak di Area T-zone \\
\hline 4 & Berjerawat \\
\hline 5 & Urat nadi tampak di area wajah \\
\hline 6 & Mudah terkelupas \\
\hline 7 & Gatal pada wajah \\
\hline 8 & Pori - pori halus \\
\hline 9 & Pori-pori besar \\
\hline
\end{tabular}

Tabel 3. Basic Pengetahuan

\begin{tabular}{|c|c|c|c|c|c|c|}
\hline $\begin{array}{c}\text { Kode } \\
\text { pengetahuan }\end{array}$ & $\begin{array}{c}\text { Kode jenis } \\
\text { kulit }\end{array}$ & $\begin{array}{c}\text { Nama jenis } \\
\text { kulit }\end{array}$ & Kode gejala & Nama gejala & MB & MD \\
\hline 1 & \multirow{2}{*}{$A$} & Normal & 1 & Berkomedo & 0.6 & 0.3 \\
\hline 2 & & Normal & 8 & Pori - pori halus & 0.8 & 0.1 \\
\hline 3 & \multirow{5}{*}{ B } & Kering & 1 & Berkomedo & 0.6 & 0.4 \\
\hline 4 & & Kering & 4 & Berjerawat & 0.6 & 0.4 \\
\hline 5 & & Kering & 6 & Mudah terkelupas & 0.7 & 0.1 \\
\hline 6 & & Kering & 7 & Gatal pada wajah & 0.7 & 0.1 \\
\hline 7 & & Kering & 8 & Pori - pori halus & 0.7 & 0.2 \\
\hline 8 & \multirow{5}{*}{ C } & Berminyak & 1 & Berkomedo & 0.7 & 0.1 \\
\hline 9 & & Beminyak & 2 & Berminyak seluruh wajah & 0.8 & 0.1 \\
\hline 10 & & Berminyak & 4 & Berjerawat & 0.8 & 0.1 \\
\hline 11 & & Berminyak & 7 & Gatal pada wajah & 0.6 & 0.2 \\
\hline 12 & & Berminyak & 9 & Pori - pori besar & 0.7 & 0.1 \\
\hline 13 & \multirow{5}{*}{ D } & Kombinasi & 1 & Berkomedo & 0.7 & 0.1 \\
\hline 14 & & Kombinasi & 3 & Berminyak area T-Zone & 0.8 & 0.1 \\
\hline 15 & & Kombinasi & 4 & Berjerawat & 0.8 & 0.1 \\
\hline 16 & & Kombinasi & 7 & Gatal pada wajah & 0.6 & 0.3 \\
\hline 17 & & Kombinasi & 9 & Pori - pori besar & 0.8 & 0.1 \\
\hline 18 & \multirow{5}{*}{$E$} & Sensitif & 1 & Berkomedo & 0.6 & 0.3 \\
\hline 19 & & Sensitif & 4 & Berjerawat & 0.6 & 0.3 \\
\hline 20 & & Sensitif & 5 & Urat nadi tampak pd wajah & 0.8 & 0.1 \\
\hline 21 & & Sensitif & 6 & Mudah terkelupas & 0.8 & 0.1 \\
\hline 22 & & Sensitif & 7 & Gatal pada wajah & 0.7 & 0.2 \\
\hline
\end{tabular}


Ket :

MB : Measure of Belief (Nilai Kepercayaan)

MD : Measure of Disbelief (Nilai Ketidak percayaan)

Perhitungan

Gejala yang dipilih:

a. Berkomedo

b. Berminyak area t-zone

c. Berjerawat

d. Gatal

e. Pori-pori besar

Penyelesaian :

\section{A. Jenis kulit 1}

$A=$ Kulit Normal

Gejala 1

Berkomedo $: \mathrm{MB}=0.6 \quad \mathrm{MD}=0.3$

Tabel 4. Prediksi Jenis Kulit A Gejala 1

\begin{tabular}{lll}
\hline MB Lama & Kosong & 0 \\
MD Lama & Kosong & 0 \\
MB Baru & MB & 0.6 \\
MD Baru & MD & 0.3 \\
MB Sementara & MB Baru & 0.6 \\
MD Sementara & MD Baru & 0.3 \\
\hline
\end{tabular}

Hasil Certainty Factor $=$ MB Sementara - MD Sementara

$\mathrm{CF}=0.6-0.3$

$\mathrm{CF}=0.3$

B. Jenis Kulit 2

$\mathrm{B}=$ Kulit kering

*Gejala 1

Berkomedo : $\mathrm{MB}=0.6 \quad \mathrm{MD}=0.4$

Tabel 5. Prediksi Jenis Kulit B Gejala 1

\begin{tabular}{lll}
\hline MB Lama & Kosong & 0 \\
MD Lama & Kosong & 0 \\
MB Baru & MB & 0.6 \\
MD Baru & MD & 0.4 \\
MB Sementara & MB Baru & 0.6 \\
MD Sementara & MD Baru & 0.4 \\
\hline
\end{tabular}

* Gejala 2

Gatal pada wajah : $\mathrm{MB}=0.7 \quad \mathrm{MD}=0.1$

Tabel 6. Prediksi Jenis Kulit B Gejala 2

\begin{tabular}{lll}
\hline MB Lama & MB Sementara & 0.6 \\
MD Lama & MD Sementara & 0.4 \\
MB Baru & MB & 0.7 \\
MD Baru & MD & 0.1 \\
MB & MB lama + (MB Baru $\times$ & $?$ \\
Sementara & (1-MB lama)) & \\
MD & MD lama + (MD Baru $\times$ & $?$ \\
Sementara & (1-MD lama)) \\
\hline
\end{tabular}

MB Sementara = MB lama $+($ MB Baru $\times(1-$ MB lama))

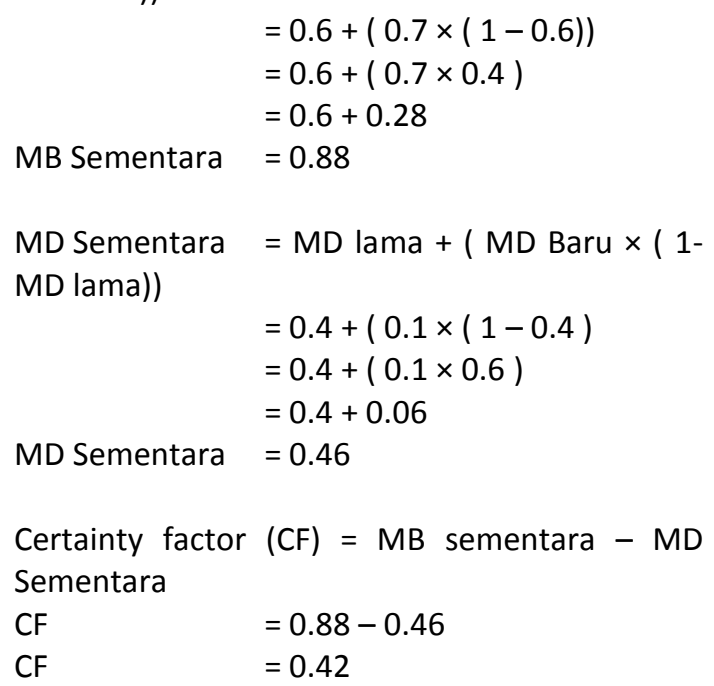

*Gejala 3

Berjerawat : $\mathrm{MB}=0.6 \quad \mathrm{MD}=0.4$

Tabel 7. Prediksi Jenis Kulit B Gejala 3

\begin{tabular}{lll} 
MB Lama & MB Sementara & 0.88 \\
MD Lama & MD Sementara & 0.46 \\
MB Baru & MB & 0.6 \\
MD Baru & MD & 0.4 \\
MB & MB lama + (MB Baru × (1- & $?$ \\
Sementara & MB lama)) & \\
MD & MD lama + (MD Baru × (1- & $?$ \\
Sementara & MD lama)) \\
\hline
\end{tabular}

MB Sementara = MB lama $+($ MB Baru $\times(1-$ MB lama))

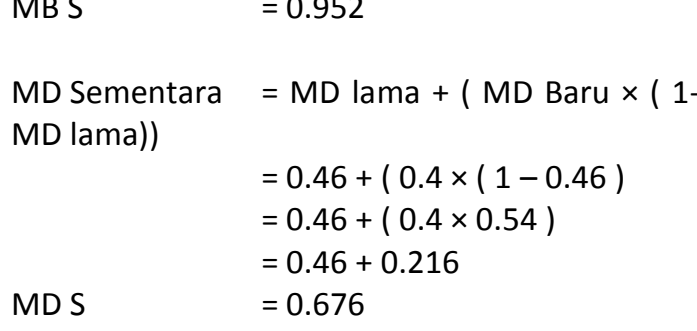

Certainty factor (CF) = MB sementara MD Sementara

$\begin{array}{ll}\mathrm{CF} & =0.952-0.676 \\ \mathrm{CF} & =0.276 \text { Kulit Kering }\end{array}$

C. Jenis Kulit 3

$\mathrm{C}=$ Kulit Berminyak

*Gejala 1

Berkomedo $: \mathrm{MB}=0.7 \quad \mathrm{MD}=0.1$ 
Tabel 8. Prediksi Jenis Kulit C Gejala 1

\begin{tabular}{lll}
\hline MB Lama & Kosong & 0 \\
MD Lama & Kosong & 0 \\
MB Baru & MB & 0.7 \\
MD Baru & MD & 0.1 \\
MB Sementara & MB Baru & 0.7 \\
MD Sementara & MD Baru & 0.1 \\
\hline
\end{tabular}

*Gejala 2

Berjerawat : $\mathrm{MB}=0.8 \quad \mathrm{MD}=0.1$

Tabel 9. Prediksi Jenis Kulit C Gejala 2

\begin{tabular}{lll}
\hline MB Lama & MB Sementara & 0.7 \\
MD Lama & MD Sementara & 0.1 \\
MB Baru & MB & 0.8 \\
MD Baru & MD & 0.1 \\
MB & MB lama + ( MB Baru × (1- & $?$ \\
Sementara & MB lama)) & \\
MD & MD lama + (MD Baru × $(1-$ & $?$ \\
Sementara & MD lama)) \\
\hline
\end{tabular}

MB Sementara = MB lama $+(\mathrm{MB}$ Baru $\times(1-$ MB lama))

$=0.7+(0.8 \times(1-0.7)$

$=0.7+(0.8 \times 0.3)$

$=0.7+0.24$

$=0.94$

MD Sementara = MD lama $+($ MD Baru $\times(1-$ MD lama))

$$
\begin{aligned}
& =0.1+(0.1 \times(1-0.1) \\
& =0.1+(0.1 \times 0.9) \\
& =0.1+0.09
\end{aligned}
$$

MD S$$
=0.19
$$

Certainty factor (CF) = MB sementara MD Sementara

$$
\begin{array}{ll}
\mathrm{CF} & =0.94-0.19 \\
\mathrm{CF} & =0.75 \text { Kulit berminyak }
\end{array}
$$

*Gejala 3

Gatal pada wajah : $\mathrm{MB}=0.6 \quad \mathrm{MD}=0.2$

Tabel 10. Prediksi Jenis Kulit C Gejala 3

\begin{tabular}{lll}
\hline & MB Sementara & 0.94 \\
MD Lama & MD Sementara & 0.19 \\
MB Baru & MB & 0.6 \\
MD Baru & MD & 0.2 \\
MB & MB lama $+($ MB Baru $\times($ & $?$ \\
Sementara & 1-MB lama $))$ & \\
MD & MD lama $+($ MD Baru $\times($ & $?$ \\
Sementara & 1-MD lama $))$ & \\
\hline & & \\
MB Sementara & $=$ MB lama $+($ MB Baru $\times(1-$ \\
MB lama $))$ & & \\
& $=0.94+(0.6 \times(1-0.94)$ \\
& $=0.94+(0.6 \times 0.06)$ \\
& $=0.94+0.036$ \\
& $=0.976$
\end{tabular}

MD Sementara = MD lama + (MD Baru $\times(1-$ MD lama))

$$
\begin{aligned}
& =0.19+(0.2 \times(1-0.19) \\
& =0.19+(0.2 \times 0.81) \\
& =0.19+0.162 \\
& =0.352
\end{aligned}
$$

\begin{tabular}{|c|c|c|}
\hline MB Lama & MB Sementara & 0.976 \\
\hline MD Lama & MD Sementara & 0.352 \\
\hline MB Baru & $\mathrm{MB}$ & 0.7 \\
\hline MD Baru & MD & 0.1 \\
\hline MB Sementara & $\begin{array}{l}\mathrm{MB} \text { lama }+(\mathrm{MB} \\
\text { Baru } \times(1-\mathrm{MB} \text { lama }))\end{array}$ & ? \\
\hline MD Sementara & $\begin{array}{l}\text { MD lama }+(\mathrm{MD} \\
\text { Baru } \times(1-\mathrm{MD} \\
\text { lama) })\end{array}$ & ? \\
\hline B Sement & \multicolumn{2}{|c|}{$=\mathrm{MB}$ lama $+(\mathrm{MB}$ Baru $\times(1$} \\
\hline & \multicolumn{2}{|c|}{$=0.976+(0.7 \times(1-0.976)$} \\
\hline & \multicolumn{2}{|l|}{$=0.976+(0.7 \times 0.024)$} \\
\hline & \multicolumn{2}{|l|}{$=0.976+0.0168$} \\
\hline & \multicolumn{2}{|l|}{$=0.9928$} \\
\hline MD Sementara & \multicolumn{2}{|c|}{$=\mathrm{MD}$ lama $+(\mathrm{MD}$ Baru $\times(1$} \\
\hline & \multicolumn{2}{|c|}{$=0.352+(0.1 \times(1-0.352)$} \\
\hline & \multicolumn{2}{|l|}{$=0.352+(0.1 \times 0.648)$} \\
\hline & \multicolumn{2}{|l|}{$=0.352+0.0648$} \\
\hline MD S & \multicolumn{2}{|l|}{$=0.4168$} \\
\hline
\end{tabular}

MD S

*Gejala 4

Pori-pori besar : $\mathrm{MB}=0.7 \quad \mathrm{MD}=0.1$

Tabel 11. Prediksi Jenis Kulit C Gejala 4

Certainty factor $(C F)=M B$ sementara $-M D$ Sementara

$\mathrm{CF} \quad=0.9928-0.4168$

$\mathrm{CF} \quad=0.576$ Kulit berminyak

D. Jenis Kulit 4

$D=$ Kulit Kombinasi

*Gejala 1

Berkomedo $: \mathrm{MB}=0.7 \quad \mathrm{MD}=0.1$

Tabel 12. Prediksi Jenis Kulit D Gejala 1

\begin{tabular}{lll} 
MB Lama & Kosong & - \\
MD Lama & Kosong & - \\
MB Baru & MB & 0.7 \\
MD Baru & MD & 0.1 \\
MB Sementara & MB lama + (MB Baru $\times$ & 0.7 \\
& (1-MB lama)) & \\
MD Sementara & MD lama + (MD Baru $\times$ & 0.1 \\
& $(1-M D$ lama)) & \\
\hline
\end{tabular}

*Gejala 2

Berminyak Area T-Zone : $\mathrm{MB}=0.8 \mathrm{MD}=0.1$ 


\begin{tabular}{lll}
\hline MB Lama & MB Sementara & 0.7 \\
MD Lama & MD Sementara & 0.1 \\
MB Baru & MB & 0.8 \\
MD Baru & MD & 0.1 \\
MB & MB lama $+($ MB Baru $\times($ & $?$ \\
Sementara & 1-MB lama $)$ & \\
MD & MD lama $+($ MD Baru $\times(~$ & $?$ \\
Sementara & 1-MD lama $)$ & \\
& & \\
MB Sementara & $=$ MB lama + MB Baru $\times(1-M B$ \\
lama)) & $=0.7+(0.8 \times(1-0.7)$ \\
& $=0.7+(0.8 \times 0.3)$ \\
& $=0.7+0.24$ \\
MD Sementara & $=$ MD lama $+($ MD Baru $\times(1-$ \\
MD lama $))$ & $=0.1+(0.1 \times(1-0.1)$ \\
& $=0.1+(0.1 \times 0.9)$ \\
& $=0.1+0.09$ \\
MD S & $=0.19$
\end{tabular}

Tabel 13. Prediksi Jenis Kulit D Gejala 2

Tabel 15. Prediksi Jenis Kulit D Gejala 4

\begin{tabular}{|c|c|c|}
\hline MB Lama & MB Sementara & 0.988 \\
\hline MD Lama & MD Sementara & 0.271 \\
\hline MB Baru & $\mathrm{MB}$ & 0.6 \\
\hline MD Baru & MD & 0.3 \\
\hline $\begin{array}{l}\text { MB } \\
\text { Sementara }\end{array}$ & $\begin{array}{l}\text { MB lama + ( MB Baru } \times \\
(1-M B \text { lama }))\end{array}$ & ? \\
\hline $\begin{array}{l}\text { MD } \\
\text { Sementara }\end{array}$ & $\begin{array}{l}\text { MD lama + ( MD Baru } \times \\
(1-\text { MD lama)) }\end{array}$ & ? \\
\hline MB Sementara & \multicolumn{2}{|c|}{$=\mathrm{MB}$ lama $+(\mathrm{MB}$ Baru $\times(1-$} \\
\hline & \multicolumn{2}{|c|}{$=0.988+(0.6 \times(1-0.988)$} \\
\hline & \multicolumn{2}{|l|}{$=0.988+(0.6 \times 0.012)$} \\
\hline & \multicolumn{2}{|l|}{$=0.988+0.0072$} \\
\hline & \multicolumn{2}{|l|}{$=0.9952$} \\
\hline \multirow{4}{*}{$\begin{array}{l}\text { MD Sementara } \\
\text { MD lama)) }\end{array}$} & \multicolumn{2}{|c|}{$=\mathrm{MD}$ lama $+(\mathrm{MD}$ Baru $\times(1-$} \\
\hline & \multicolumn{2}{|c|}{$=0.271+(0.3 \times(1-0.271)$} \\
\hline & \multicolumn{2}{|l|}{$=0.271+(0.3 \times 0.729)$} \\
\hline & \multicolumn{2}{|l|}{$=0.271+0.2187$} \\
\hline MD S & \multicolumn{2}{|l|}{$=0.4897$} \\
\hline
\end{tabular}

Certainty factor (CF) = MB sementara MD Sementara

$\mathrm{CF} \quad=0.9952-0.4897$

$\mathrm{CF} \quad=0.5055$ Kulit kombinasi

* Gejala 5

Pori - pori besar : $\mathrm{MB}=0.8 \quad \mathrm{MD}=0.1$

Tabel 16. Prediksi Jenis Kulit D Gejala 5

\begin{tabular}{lll} 
MB Lama & MB Sementara & 0.9952 \\
MD Lama & MD Sementara & 0.4897 \\
MB Baru & MB & 0.8 \\
MD Baru & MD & 0.1 \\
MB Sementara & MB lama + (MB Baru & $?$ \\
& $\times(1-M B$ lama $)$ & \\
MD Sementara & MD lama + (MD Baru & $?$ \\
& $\times(1-M D$ lama $))$ & \\
\hline
\end{tabular}

MB Sementara = MB lama $+($ MB Baru $\times(1-$ MB lama))

MB Sementara $=$ MB lama $+(\mathrm{MB}$ Baru $\times(1$ MB lama))

$\begin{array}{lll}\text { MB Lama } & \text { MB Sementara } & 0.94 \\ \text { MD Lama } & \text { MD Sementara } & 0.19 \\ \text { MB Baru } & \text { MB } & 0.8 \\ \text { MD Baru } & \text { MD } & 0.1 \\ \text { MB Sementara } & \text { MB lama + (MB Baru } & ? \\ & \times(\text { 1-MB lama)) } & \\ \text { MD Sementara } & \text { MD lama + ( MD Baru } & ? \\ & \times(\text { 1-MD lama)) }\end{array}$

$\begin{array}{ll} & =0.94+(0.8 \times(1-0.94) \\ & =0.94+(0.8 \times 0.06) \\ & =0.94+0.048 \\ & =0.988 \\ \text { MD Sementara } & =\text { MD lama }+(\text { MD Baru } \times(1- \\ \text { MD lama })) & \\ & =0.19+(0.1 \times(1-0.19) \\ & =0.19+(0.1 \times 0.81) \\ \text { MD S } & =0.19+0.081 \\ * \text { Gejala 4 } & =0.271 \\ \text { Gatal pada wajah } & : \text { MB }=0.6 \quad \text { MD }=0.3\end{array}$



Certainty factor (CF) = MB sementara MD Sementara

$\mathrm{CF}=0.99904-0.54073$

$\mathrm{CF} \quad=0.45831$ Kulit kombinasi 


\section{E. Jenis Kulit 5}

$E=$ Kulit Sensitif

*Gejala 1

Berkomedo : $\mathrm{MB}=0.6$

$\mathrm{MD}=0.3$

Tabel 17. Prediksi Jenis Kulit E Gejala 1

\begin{tabular}{lll} 
MB Lama & Kosong & - \\
MD Lama & Kosong & - \\
MB Baru & MB & 0.6 \\
MD Baru & MD & 0.3 \\
MB & MB lama + (MB Baru $\times$ & 0.6 \\
Sementara & $($ (1-MB lama)) & \\
MD & MD lama + (MD Baru $\times$ & 0.3 \\
Sementara & $($ (1-MD lama)) & \\
\hline
\end{tabular}

*Gejala 2

Berjerawat : $\mathrm{MB}=0.6$

$\mathrm{MD}=0.3$

Tabel 18. Prediksi Jenis Kulit E Gejala 2

\begin{tabular}{lll}
\hline MB Lama & MB Sementara & 0.6 \\
MD Lama & MD Sementara & 0.3 \\
MB Baru & MB & 0.6 \\
MD Baru & MD & 0.3 \\
MB & MB lama + (MB Baru $\times$ & $?$ \\
Sementara & (1-MB lama)) & \\
MD & MD lama + (MD Baru $\times$ & $?$ \\
Sementara & (1-MD lama))
\end{tabular}

Sementara (1-MD lama))

MB Sementara $=\mathrm{MB}$ lama $+(\mathrm{MB}$ Baru $\times(1-$ MB lama))

$=0.6+(0.6 \times(1-0.6)$

$=0.6+(0.6 \times 0.4)$

$=0.6+0.24$

$=0.84$

MD Sementara $=$ MD lama $+($ MD Baru $\times(1-$

MD lama))

MD S

$$
\begin{aligned}
& =0.3+(0.3 \times(1-0.3) \\
& =0.3+(0.3 \times 0.7) \\
& =0.3+0.21 \\
& =0.51
\end{aligned}
$$

Certainty factor (CF) = MB sementara MD Sementara

$$
\begin{array}{ll}
\text { CF } & =0.84-0.51 \\
\text { CF } & =0.33 \text { Kulit kombinasi }
\end{array}
$$

*Gejala 3

Gatal Pada wajah : $\mathrm{MB}=0.7 \quad \mathrm{MD}=0.2$

Tabel 19. Prediksi Jenis Kulit E Gejala 3

\begin{tabular}{lll}
\hline MB Lama & MB Sementara & 0.84 \\
MD Lama & MD Sementara & 0.51 \\
MB Baru & MB & 0.7 \\
MD Baru & MD & 0.2 \\
MB Sementara & MB lama + (MB Baru $\times($ & $?$ \\
& 1-MB lama)) & \\
MD Sementara & MD lama + (MD Baru $\times($ & $?$ \\
& 1-MD lama))
\end{tabular}

MB Sementara $=$ MB lama $+(\mathrm{MB}$ Baru $\times(1-$ MB lama))

$$
\begin{aligned}
& =0.84+(0.7 \times(1-0.84) \\
& =0.84+(0.7 \times 0.16) \\
& =0.84+0.112 \\
& =0.952
\end{aligned}
$$

MD Sementara = MD lama $+($ MD Baru $\times(1-$ MD lama))

$$
\begin{aligned}
& =0.51+(0.2 \times(1-0.51) \\
& =0.51+(0.2 \times 0.49) \\
& =0.51+0.098 \\
& =0.608
\end{aligned}
$$

MD S

Certainty factor (CF) = MB sementara MD Sementara

$$
\begin{array}{ll}
\text { CF } & =0.952-0.608 \\
\text { CF } & =0.344 \text { Kulit kombinasi }
\end{array}
$$

\subsection{Implementasi}

\subsubsection{Analisa Kebutuhan}

A. Use Case Diagram

Use case diagram menggambarkan kebutuhan sistem dari sudut pandang di luar sistem. Adapun use case diagram pada Aplikasi sistem pakar penentuan jenis kulit wajah pada d'tops by jafra. Rancangan use case diagram dapat dilihat pada gambar 6 .

\section{B. Activity Diagram}

Diagram aktivitas atau activity diagram menggambarkan aktivitas yang dapat dilakukan oleh sistem. Rancangan diagram aktivitas untuk menentukan jenis kulit wajah tampak pada gambar 2 - 5



Gambar 2. Activity Diagram Halaman Utama 


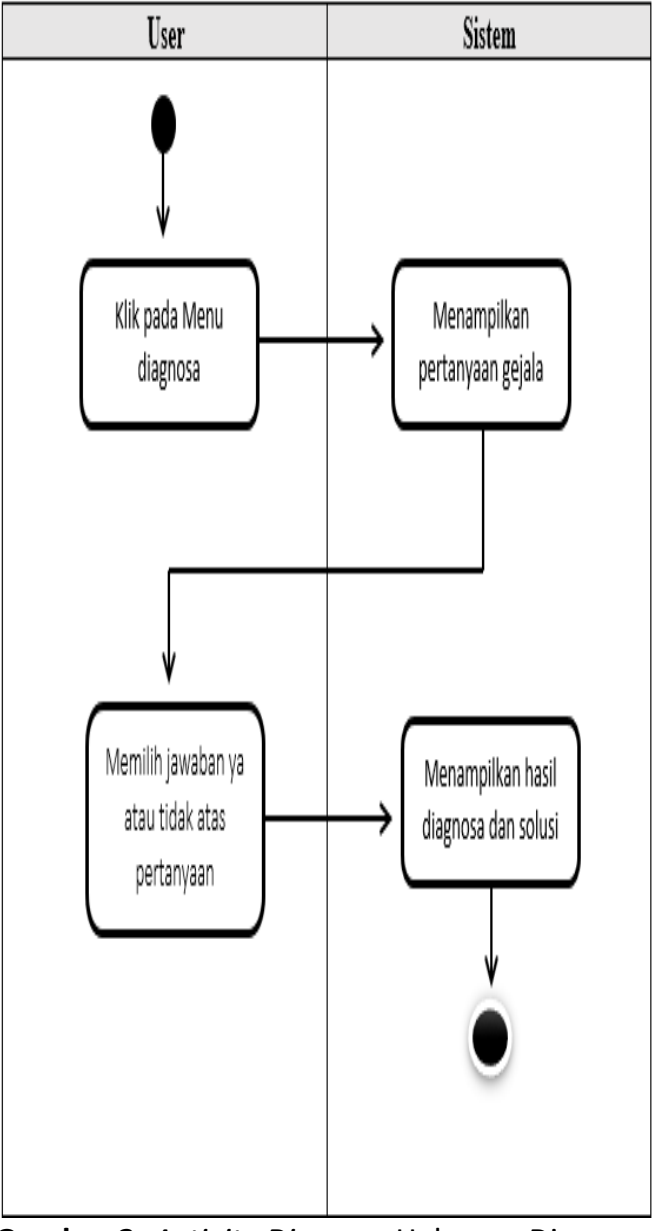

Gambar 3. Activity Diagram Halaman Diagnosa



Gambar 4. Activity Diagram Informasi Jenis Kulit

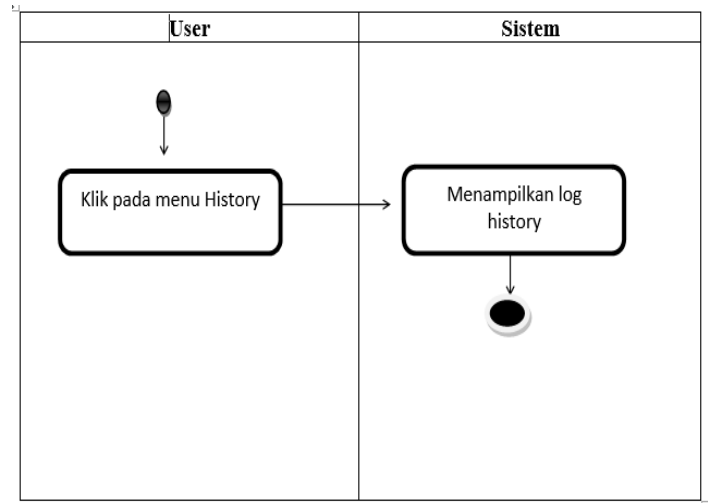

Gambar 5. Activity Diagram History

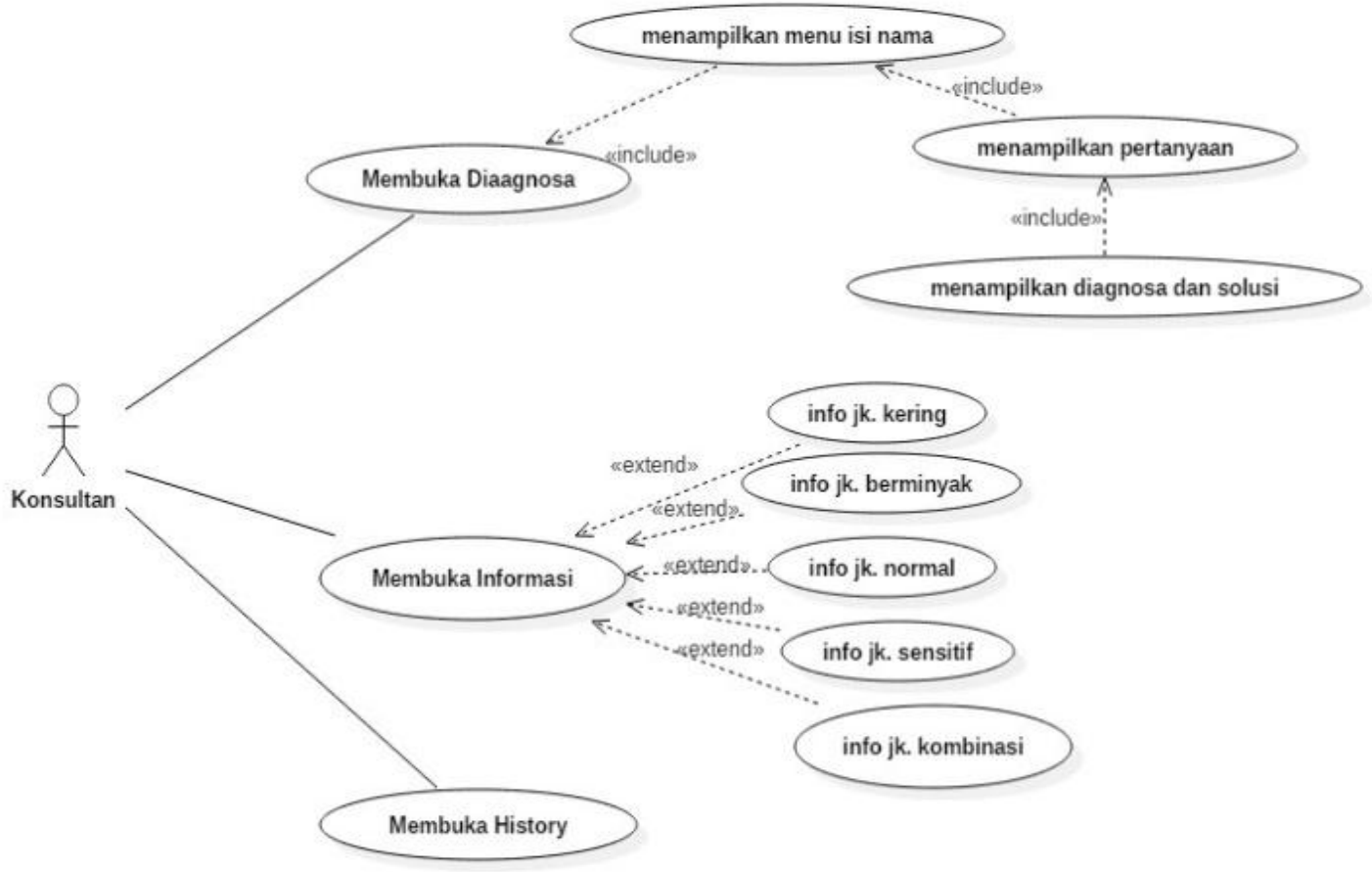

Gambar 6. Use Case Diagram Sistem 


\section{Entity Realationship Diagram (ERD)}

Berdasarkan basis data yang ada, pemetaan tabel-tabel dan relasinya dapat digambarkan dengan Entity Relationship Diagram (ERD) sebagai seperti tampak pada gambar 7.

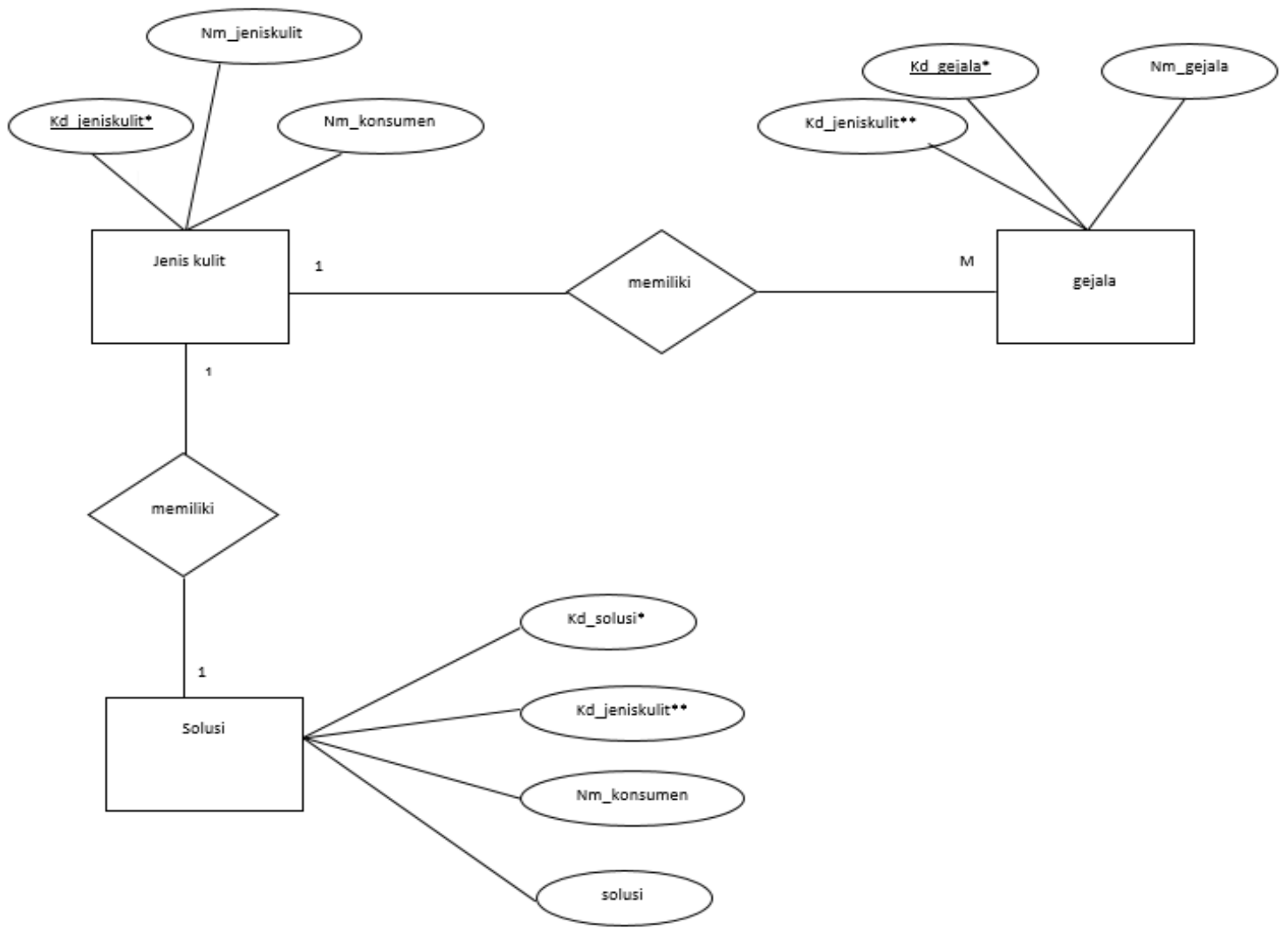

Gambar 7. Entity Realationship Diagram (ERD)

\section{Logical Record Structure}

\begin{tabular}{|c|c|c|c|}
\hline Jenis Kulit & \multirow{5}{*}{ memiliki } & & \\
\hline Kd__eniskulit* & & $M$ & gejala \\
\hline Nm_jenisKulit & & \multirow[b]{5}{*}{1} & Kd_gejala = \\
\hline Nm_konsumen & & & Kd_jeniskulit*: \\
\hline 1 & & & Nm_gejala| \\
\hline & & & solusi \\
\hline & & & Kd_solusi* \\
\hline & & & Kd_jeniskulit*: \\
\hline & & & Solusi \\
\hline & & & $\mathrm{Nm}$ _konsumen \\
\hline
\end{tabular}

Gambar 8. Logical Record Structur 


\section{E. Prototype}

Antar muka Aplikasi yang di implementasikan merupakan antar muka aplikasi sistem pakar untuk menentukan jenis kulit wajah yang diimplementasikan pada smartphone android.

1) Tampilan Halaman Splash Screen

Pada saat memulai aplikasi, akan muncul halaman splash.

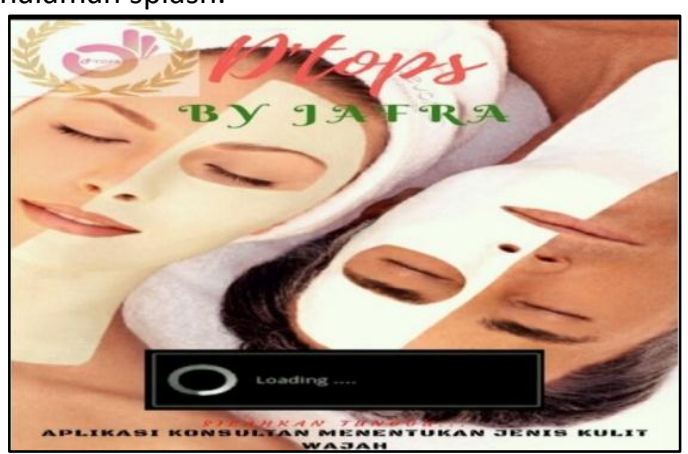

Gambar 9. Tampilan Halaman Splash Screen

\section{2) Tampilan Halaman Utama}

Setelah screen splash akan terdirect sendiri kehalaman utama. Pada halaman menu utama ini terdapat 3 menu yaitu menu diagnosa, Info Jenis-jnis Kulit, dan History.

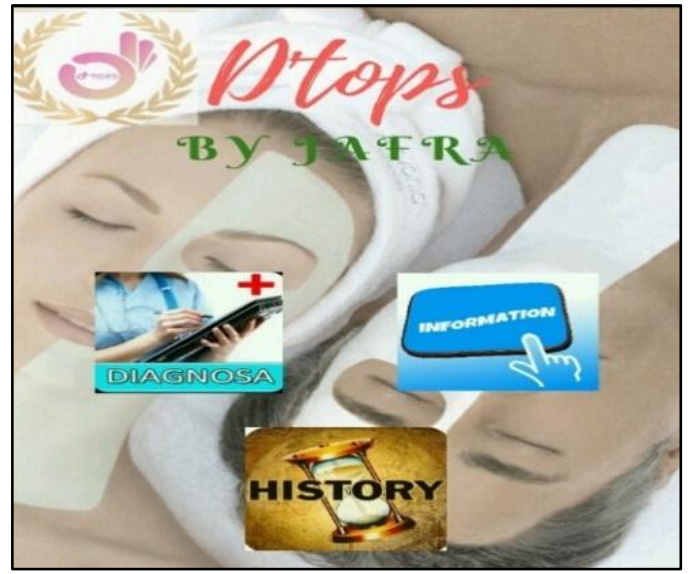

Gambar 10. Tampilan Halaman Utama

3) Tampilan Halaman Menu Isi Nama

Ketika menu diagnosa dipilih, akan muncul isian terlebih dahulu isian nama konsumen

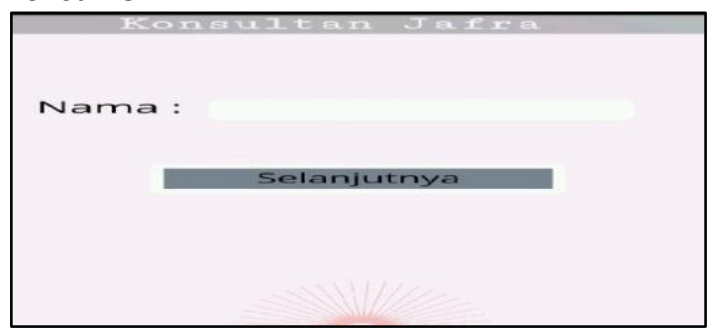

Gambar 11. Tampilan Halaman Menu Isi Nama
4) Interface Halaman Pertanyaan

Setelah input nama pada menu diagnose kemudian muncul pertanyaan - pertanyaan gejala yang harus dijawab oleh user berdasarkan ciri - ciri yang dirasakan konsumen.

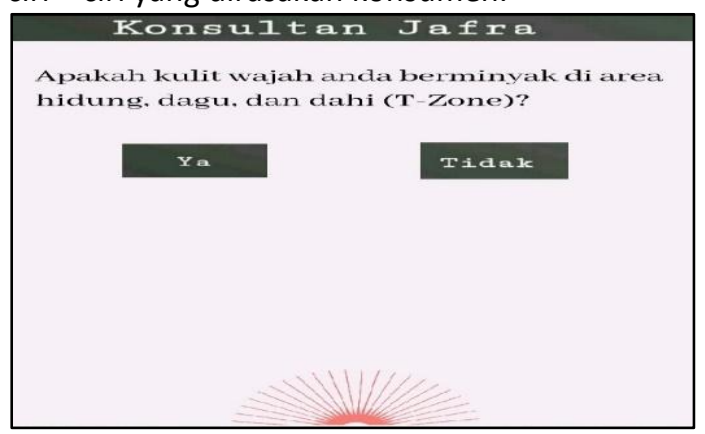

Gambar 12. Tampilan Halaman Pertanyaan

5) Interface halaman diagnosa dan solusi Setelah menjawab pertanyaanpertanyaan gejala, sistem akan melakukan prose diagnosa sesuai perhitungan menggunakan certainty factor dan hasilnya akan ditampilkan seperti pada gambar 13 .

\begin{tabular}{|c|c|}
\hline $\begin{array}{l}\text { Nama : Rangga Pebrianto } \\
\text { Jenis Kulit Berminyak }\end{array}$ & \\
\hline 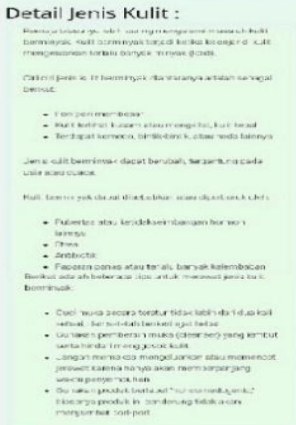 & $\begin{array}{l}\text { Solusi Perawatan Produk Jafra : } \\
\text { JAFRA Mattifying Advanced } \\
\text { Dynamics Series }\end{array}$ \\
\hline
\end{tabular}

Gambar 13. Tampilan Halaman Diagnosa dan Solusi

6) Tampilan Halaman Informasi Jenis Kulit Ketika user memilih menu informasi jenis-jenis kulit sistem akan menampilkan halaman berisi daftar nama jenis kulit.

\begin{tabular}{|l|}
\hline \multicolumn{1}{|c|}{ Konsultan Jafxa } \\
Kulit Kering \\
Kulit Berminyak \\
Kulit Kombinasi \\
Kulit Normal \\
Kulit Sensitif \\
\end{tabular}

Gambar 14. Tampilan Halaman Informasi Jenis Kulit 
7) Tampilan Halaman PopUp Informasi Jenis Kulit

Setelah memilih salah satu jenis kulit dari list jenis kulit maka akan muncul popUp infromasi Jenis kulit yang dipilih seperti terlihat pada gambar 15 .

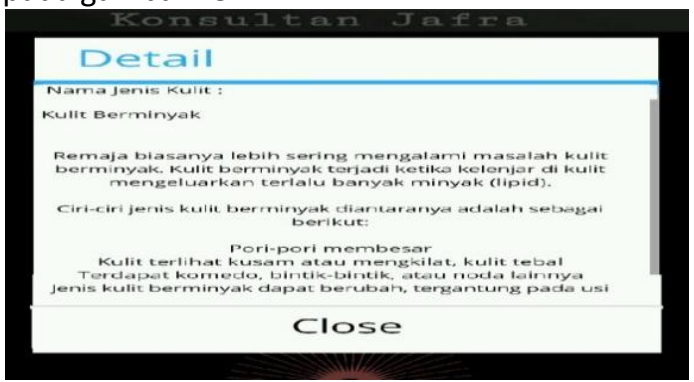

Gambar 15. Tampilan Halaman PopUp Informasi Jenis Kulit

8) Tampilan Halaman History

Ketika User memilih menu History, maka sistem akan menampilkan halaman berisi log history (Nama,waktu akses dan hasil diagnosa) seperti pada gambar 16.

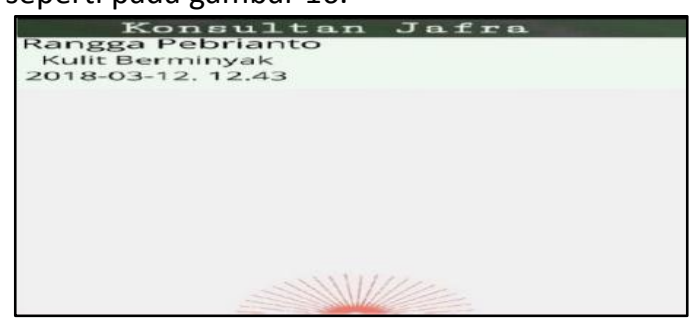

Gambar 16. Tampilan Halaman History

\section{KESIMPULAN}

Aplikasi mobile yang dirancang merupakan suatu sistem pakar yang dapat dibawa kemana saja untuk meningkatkan ketepatan dan keefektifan dalam mendiagnosa jenis wajah dan membeikan solusi untuk konsumen. Dengan aplikasi ini konsultan dapat melakukan pemeriksaan dengan mudah karena hanya membuka aplikasi android. Pendiagnosaan dengan metode certainty factor ini dapat memberikan hasil diagnosa serta dapat memberikan solusi produk yang tepat berdasarkan jenis kulit yang di diagnosa oleh sistem. Maka dengan adanya aplikasi ini proses menentukan jenis kulit wajah dapat terselesaikan secara cepat dan tepat.

\section{REFERENSI}

Berliana, C. G. (2015). Sistem Pakar Masalah Kulit Untuk Penentuan Ketepatan Perawatan Wajah Berminyak Dengan Metode Forward Chaining.
Diah, S., \& Murti, H. (2014). Sistem Pakar Diagnosa Virus Komputer Berbasis Web Setiyani Diah , Hari Murti. Dinamika Informatika, 6(2), 110-118.

Durkin, J. (1994). Expert System Design and Development (Prentice H). London.

Hernawan, H., \& Sidiq, P. (2018). Pengembangan Sistem Pakar sebagai Bahan Ajar dalam Pembelajaran Fisiologi Hewan sub Materi Fisiologi Sirkulasi. Jurnal Petik, 2(2), 17. https://doi.org/10.31980/jpetik.v2i2.70

Permatasari, S. D. (2019). Perancangan sistem pakar diagnosa jenis kulit wajah wanita dalam memilih kosmetik. UNIVERSITAS PASUNDAN BANDUNG.

Putra, I. P. I. A., \& Winaya, K. K. (2018). Pengaruh personal hygiene terhadap timbulnya akne vulgaris pada mahasiswa Program Studi Pendidikan Dokter angkatan 2014 di Fakultas Kedokteran Universitas Udayana. Intisari Sains Medis, 9(2), 156-159. https://doi.org/10.1556/ism.v9i2.258

Santi, I. H., \& Andari, B. (2019). Sistem Pakar Untuk Mengidentifikasi Jenis Kulit Wajah dengan Metode Certainty Factor. INTENSIF: Jurnal Ilmiah Penelitian Dan Penerapan Teknologi Sistem Informasi, $3(2)$,

159. https://doi.org/10.29407/intensif.v3i2.12 792

Saputra, A. (2017). Sistem Pakar Diagnosa Penyakit Kulit Menggunakan Metode Forward Chaining.

Septiana, L. (2016). Perancangan Sistem Pakar Diagnosa Penyakit Ispa Dengan Metode Certainty Factor Berbasis Android. None, 13(2), 1-7.

Syatibi, A. (2019). Sistem Pakar Diagnosa Awal Penyakit Kulit Sapi Berbasis Web Dengan Menggunakan Metode Certainty Factor (Vol. https://doi.org/10.1017/CBO9781107415 324.004

Wardah, N. N., Sugiarto, A., \& Wibowo, A. H. (2019). Sistem Pakar Identifikasi Kerusakan Kulit Wajah untuk Proses Aesthetic and Anti Aging. Prosiding Seminar Nasional Sisfotek (Sistem Informasi Dan Teknologi Informasi), Vol . 3(1), 37-43. 